\title{
JUVENILE XANTHOGRANULOMA* REPORT OF A CASE
}

\author{
BY
}

\author{
J. GIBSON MOORE AND JOHN HARRY \\ Chase Farm Hospital, Enfield, Middlesex
}

and the Department of Pathology, Institute of Ophthalmology, University of London

JUVENILE xanthogranuloma, also commonly known as naevoxantho-endothelioma, was first described as a skin disease in 1909 (McDonaugh, 1909), but it was not until forty years later that the first intra-ocular case was reported in America (Blank, Eglick, and Beerman, 1949). Some twenty to thirty cases have since been described (Sanders, 1962), but our case is the first to be reported in the United Kingdom.

\section{Case Report}

A 12-month-old boy was first seen on January 12, 1962. The parents stated that one week previously they had noticed a yellow mass in the pupil of the right eye.

Examination.-There was a large mass on the iris extending from 3 to 7 o'clock involving the pupillary margin together with an area of vascularization at the edge of the pupil, but no sign of haemorrhage into the anterior chamber (Fig. 1).

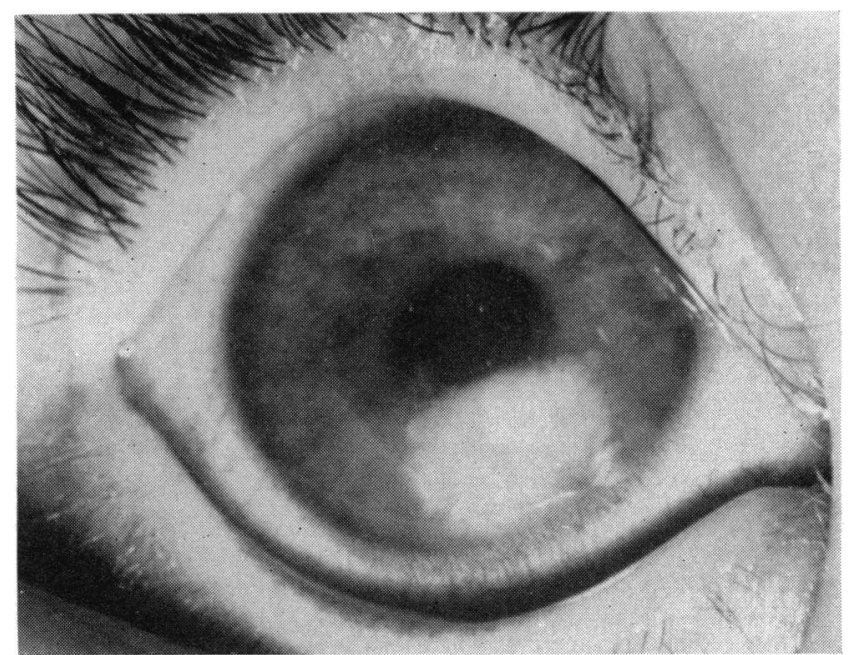

FIG. 1.-Right eye of patient showing iris tumour in lower nasal quadrant.

Examination under General Anaesthesia.-The cornea was seen to be clear and the fundus normal, but gonioscopy revealed that the mass on the iris was spreading into the filtration angle. At that time the intra-ocular pressure was $16 \mathrm{~mm}$. $\mathrm{Hg}$ (Schiötz). Apart from the presence of this iris tumour the child appeared healthy and no skin lesions were detected.

Operation.-A tentative diagnosis of malignant iris tumour having been made, the lesion was removed by performing a large iridectomy on February 12,1962. During the period of one month which had elapsed since the child was first seen the tumour had enlarged, and at the time of operation it occupied approximately one-third of the iris. From a technical viewpoint the operation was

\footnotetext{
* Received for publication April 14, 1964.
} 
difficult; not only was the tumour in the lower nasal quadrant of the iris, but it was friable and could only be removed by a radial incision into healthy iris tissue on either side and cutting across the root. There was considerable haemorrhage at the operation, at the conclusion of which there was a total hyphaema. The wound was closed with three corneoscleral sutures. It was considered that removal had not been complete and that tumour remnants remained in the angle of the anterior chamber.

Post-operative Course.-During the first few days after the operation the hyphaema appreciably lessened in amount, but the cornea became oedematous and the intra-ocular pressure rose to $48 \mathrm{~mm}$. $\mathrm{Hg}$ (Schiötz).

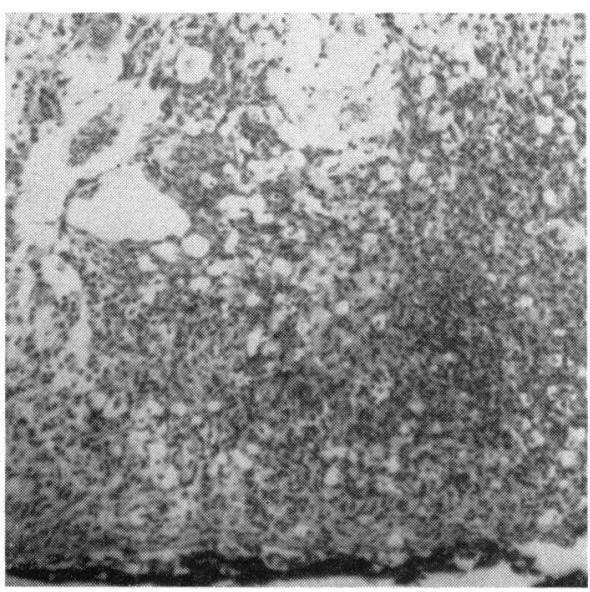

FIG. 2.-Iris tumour showing diffuse monocytic cellular infiltration. $H$. and $E$. $\times 80$.

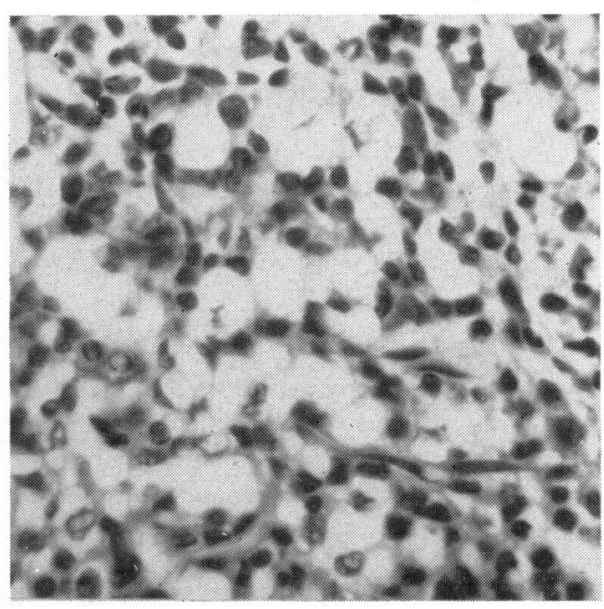

FIG. 3.-Iris tumour showing diffuse monocytic cellular infiltration. The typical vacuolated cytoplasm is well seen. H. and E. $\times 385$.

Pathological Report.-Sections of the tumour showed the iris stroma to be diffusely infiltrated with monocytic cells (Fig. 2), some of which had a clear eosinophilic cytoplasm, while others had a foamy lipid cytoplasm giving rise to a vacuolated appearance (Fig. 3). Several typical Touton giant cells (Fig. 4) consisting of a lipid cytoplasm with a ring of nuclei were seen, together with an occasional foreign body giant cell (Fig. 5). A number of small blood vessels

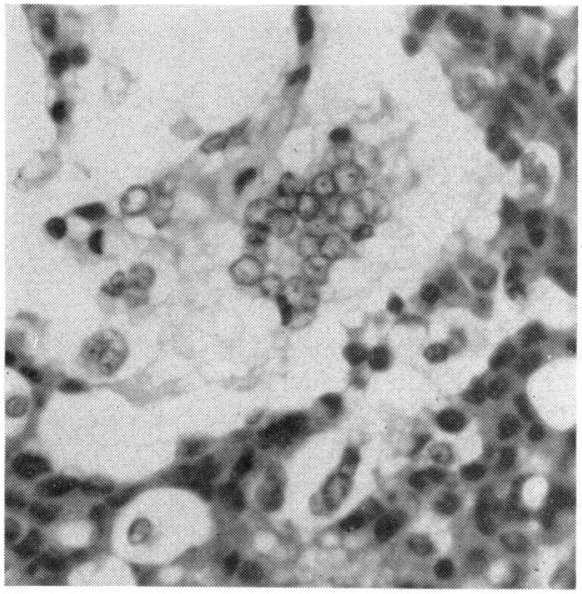

FIG. 4.-Multinucleated Touton giant cell with foamy vacuolated cytoplasm. $\mathrm{H}$. and $\mathrm{E} . \times 385$.

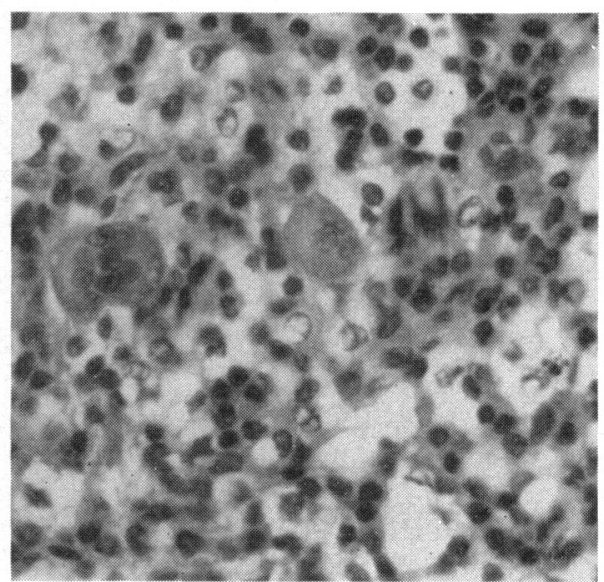

FIG. 5.-Few foreign body giant cells lying among monocytic cells. H. and E. $\times 385$. 


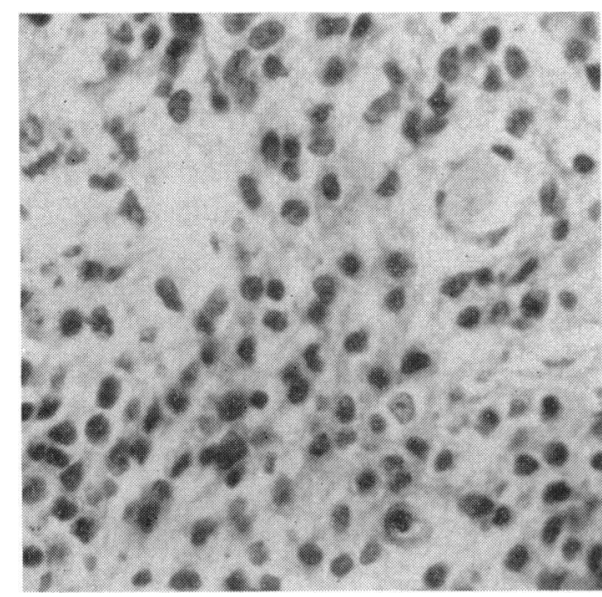

Fig. 6.-Portion of iris tumour showing a blood vessel. H. and $\mathrm{E}$. $\times 385$.

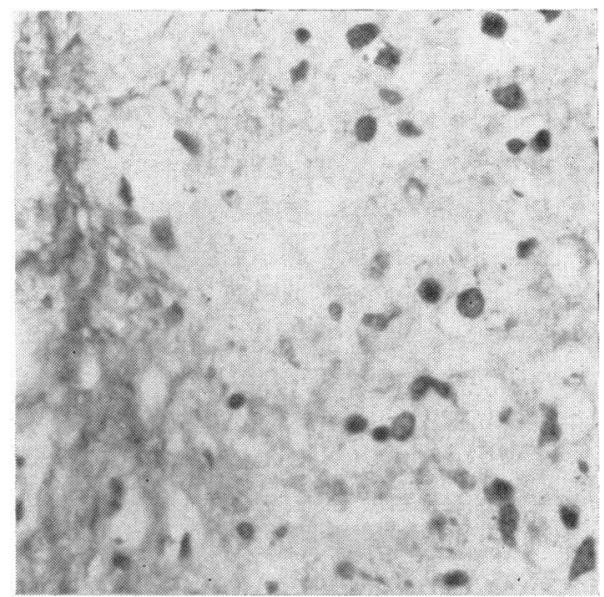

Fig. 7.-Extensive area of necrosis in tumour. H. and E. $\times 385$.

was present (Fig. 6) and there was a little haemorrhage in addition to some necrosis (Fig. 7). The histological appearance was that of xanthogranuloma.

Follow-up.-On February 24, 1962, the patient was referred to Dr. V. B. Levison at the North Middlesex Hospital for radiotherapy, and two doses of $200 \mathrm{r}$ were given at an interval of 7 days. The result of this treatment was quite dramatic. After 10 days the corneal oedema disappeared, the eye became white, and the iris pillars free. There were no lens opacities, but a circular ring of pigment, the size of the normal pupil, was observed on the anterior surface of the lens.

In view of the diagnosis a further search for skin lesions was made but none was found. The following investigations were performed: $X$ ray of skull and long bones-no abnormality detected; blood count-normal; blood cholesterol-240 mg./100 ml.; urine examination-negative.

It is now over two years since the lesion was removed. The eye has remained quiet and there has been no recurrence of the tumour (Fig. 8).

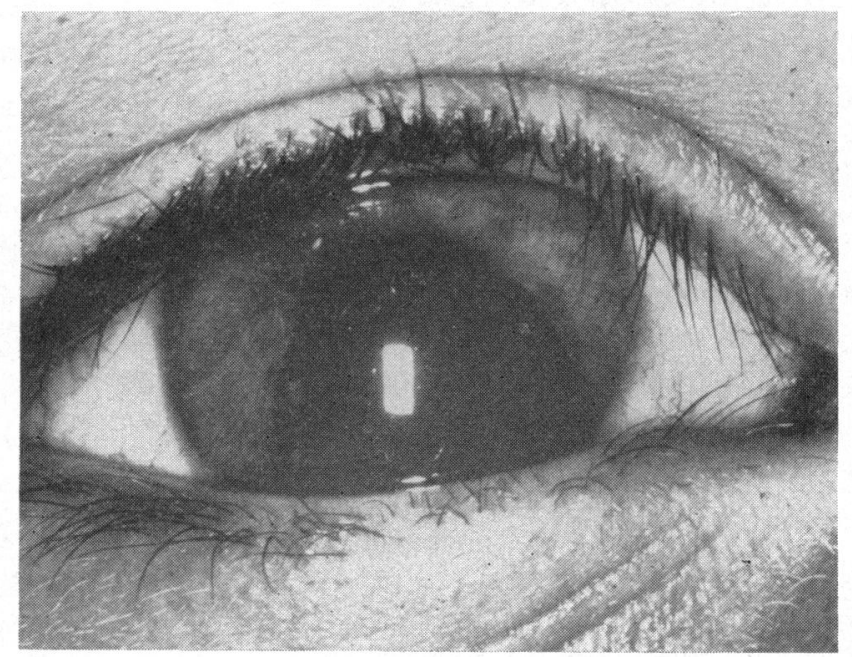

FIG. 8.-Right eye of patient two years after operation showing broad iridectomy. 


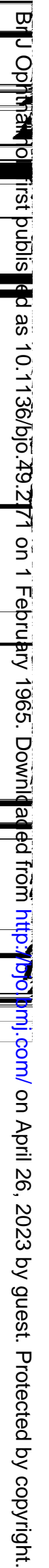


lesion with hyphaema and/or secondary glaucoma. In order to prevent unnecessary enucleation it is of considerable importance to make the correct diagnosis, and this can be established either from the typical clinical picture or from the histological appearance of skin or iris biopsy.

\section{Summary}

A case of juvenile xanthogranuloma in a male infant aged 12 months is reported. The pathology and possible pathogenesis of the lesion are discussed.

Our thanks are due to Professor Norman Ashton for advice, to Miss E. M. FitzGerald and Miss C. B. Morris for secretarial help, and to Mr. V. J. Elwood and the Department of Medical Illustration at the Institute of Ophthalmology for assistance with the photography.

\section{REFERENCES}

Blank, H., Eglick, P. G., and Beerman, H. (1949). Pediatrics, 4, 349.

Crocker, A. C. (1951). Ibid., 8, 573.

Hassenpflug, K. (1957). Derm. Wschr., 136, 1345.

Hedges, C. C., Jr. (1959). Amer. J. Ophthal., 47, 683.

Helwig, E. B. (1957). Proc. Pacific Coast Derm. Ass., pp. 25-28.

Hogan, M. J. (1962). Personal communication quoted by Sanders (1962).

Lamb, J. H., and Lain, E. S. (1937). Sth. med. J. (Bgham, Ala.), 30, 585.

McDonaugh, J. E. R. (1909). Brit. J. Derm., 21, 254.

Maumenee, A. E. (1956). Trans. Amer. Acad. Ophthal. Otolaryng., 60, 401.

and Longfellow, D. W. (1960). Amer. J. Ophthal., 49, 1.

Newell, F. W. (1957). Arch. Ophthal., 58, 321.

NiLSBY, J. (1952). Acta paediat. (Uppsala), 41, 373.

Nomland, R. (1954). J. invest. Derm., 22, 207.

OrmsBy, O. S., and MonTGOMery, H. (1954). "Diseases of the Skin", 8th ed., p. 745. Lea, Philadelphia. SANDERS, T. E. (1962). Amer. J. Ophthal., 53, 455.

ThanNhauser, S. J. (1958). "Lipidoses", 3rd ed. Grune and Stratton, New York. 